\title{
Biochemical Changes in Hepatic Function of Petrol Station Attendants in Basrah
}

\author{
Majid S. Jabir , Omar A. Khalil, Zainab J. Taqi and Huda A. Hussain \\ Applied Science Department, University of Technology.
}

\begin{abstract}
Previous studies on human and animals demonstrated that many of chemicals components of petroleum can affect the liver function. The present study investigated and evaluated the hepatotoxic effects of petroleum fumes and the changes in liver biochemical functions resulted from exposure to petrol and their derivatives by measuring the changes of liver enzymes and total serum bilirubin in 18 petrol workers station attendant in Basrah, Iraq. A corresponding 18healthy subjects were used as controls. Biochemical analyses on the serum samples were done after samples collection. Results are time exposure dependent. Our results showed the presence of a significant increase in the level of Glutamic-pyruvic transaminase (GOT), Glutamic-oxaloacetic transaminase (GPT), Alkaline phosphatase ALP and they related to the time of exposure to petroleum products especially for 3-6 years, and for 6-10 years, $p$ value was $p \leq 0.01, p \leq 0.001$ respectively. Total serum bilirubin TSB for those workers which were exposed to petrol from six to ten years were also showed a significantly higher than the control. These effects may be directly related to time of exposure. The study suggests that long term inhalation of petrol fumes is associated with adverse effect on liver function.
\end{abstract}

Keywords: Liver function, GOT, GPT, ALP, TSB, Petrol station.

\section{Introduction}

Petroleum products are widely used for energy and home heating system they covered by the Oil Spill Law. The common examples of petroleum products are kerosene, diesel fuel, and gasoline. Petroleum products are chemical complex mixtures derived from oil and most of them have similar physical, and chemical properties. They contain huge numbers of hydrocarbon chemicals in varying proportions, and a variety of additives They contain hundreds of hydrocarbon chemicals in varying proportions, and a variety of additives [1][2]. Gasoline is a complex; volatile, and inflammable [3]. It contains chemicals such as benzene and the (MTBE) [4]. Fuel products are mixtures of chemical materials such as hydrocarbons, aromatic, and aliphatic related to gasoline, all of them have side effect and can be affect many organs such as liver and urinary tract $[5,6]$, which may be increase in production of toxic metabolites including ROS. Most human have a high risk due to exposure to petroleum products and their derivatives [7]. The nature of chemical products of gasoline makes them presentin the environmenteach time especially at petroleum stations. A lot of People who are exposed to petrol fumes during their duty at gas stations, but the people who are working at filling station are more dangerous by virtue of their occupational exposure [8],[9]. Our study aimed to measure the changes in liver enzymes and total serum bilirubin. A Blood sample was taken from subject and serumpreparation then biochemical analyses on the serum samples were done. Gasoline-filling workers showed marked change in biochemical evidence of impaired liver function, which may be directly correlated to the duration time of exposure.

\section{Materials and Methods Samples collection}

A total of 36 human subjects were used in the study: Eighteen workers attendants in Basrah All the workers are exposed to petrol products during their duties (18) Health ysubjectshealthy people were recruited as negative controls for the study. Blood samples $(5 \mathrm{ml})$ were taken from each subject and put it into a plain tube for serum preparation. Serum samples were separated after collection of blood by centrifugation at 5000 RPM for $10 \mathrm{~min}$; samples were stored in a refrigerator. 


\section{Liver function assay}

Biochemical analyses of the serum samples were done 24hr. after sample collection. Biochemical analyses were carried out for the liver function test GOT, GPT, ALP, and TSB. Kit's reagents from Ran dox (UK) were used in this study for all analyses and the absorbance was read using a UV-Vis spectrophotometer (DREL $3000 \mathrm{HACH}$ ) at $520 \mathrm{~nm}$.

\section{Statistical analysis}

Student's $t$-test was used to compare means in our study. $P \leq 0.05$ was considered statistically significant.

\section{Results and Discussion}

The level of GOT, GPT, and ALP for workers who exposed to petroleum products such as kerosene and gasoline were compared with non-exposed subjects. Our results are expressed in a time exposure dependent manner. The levels of GOT, GPT, and ALP showed asignificant increases with increasing the time of exposure to kerosene and gasoline (Fig. 1, 2, and 3) respectively.

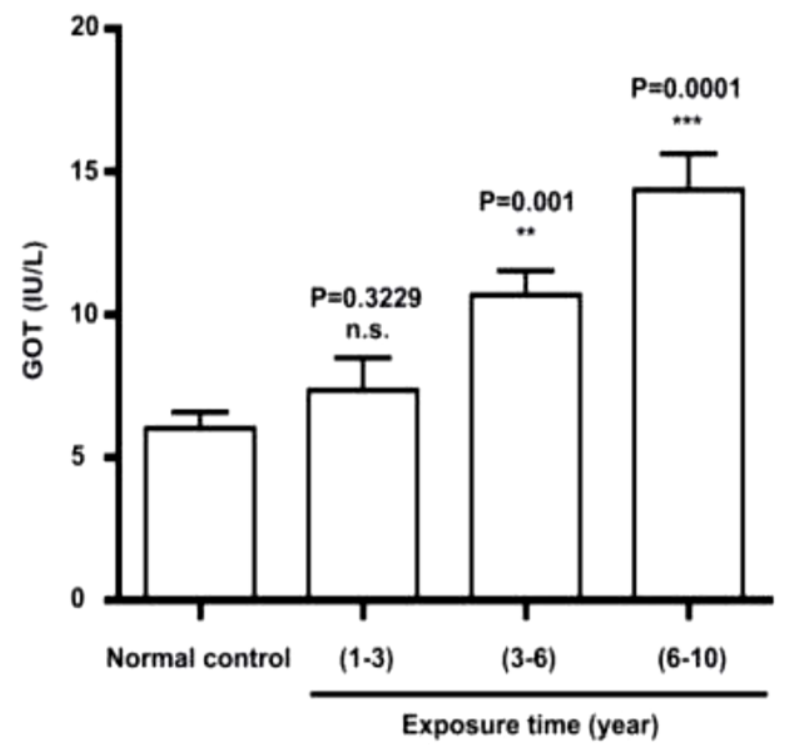

Fig.(1): GOT level in petrol station workers compared with non-exposed subjects. Asterisks indicate statistically different. Columns are mean of six determinations.

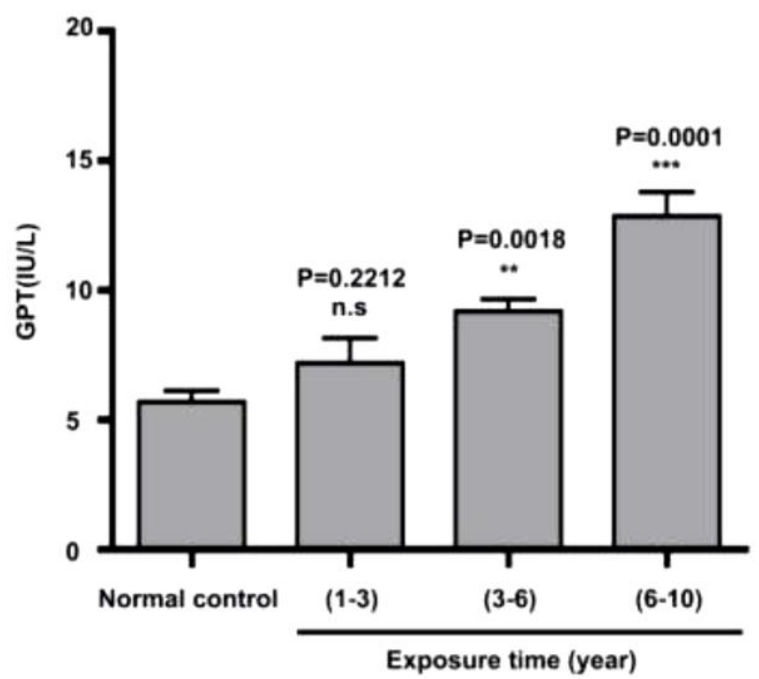

Fig.(2): GPT level in petrol station workers compared with non-exposed subjects.

Asterisks indicate statistically different.

Columns are mean of six determinations.

Total serum bilirubin level showed no significant differences between workers except the group of 6-10years exposed to petroleum products Fig.(4).

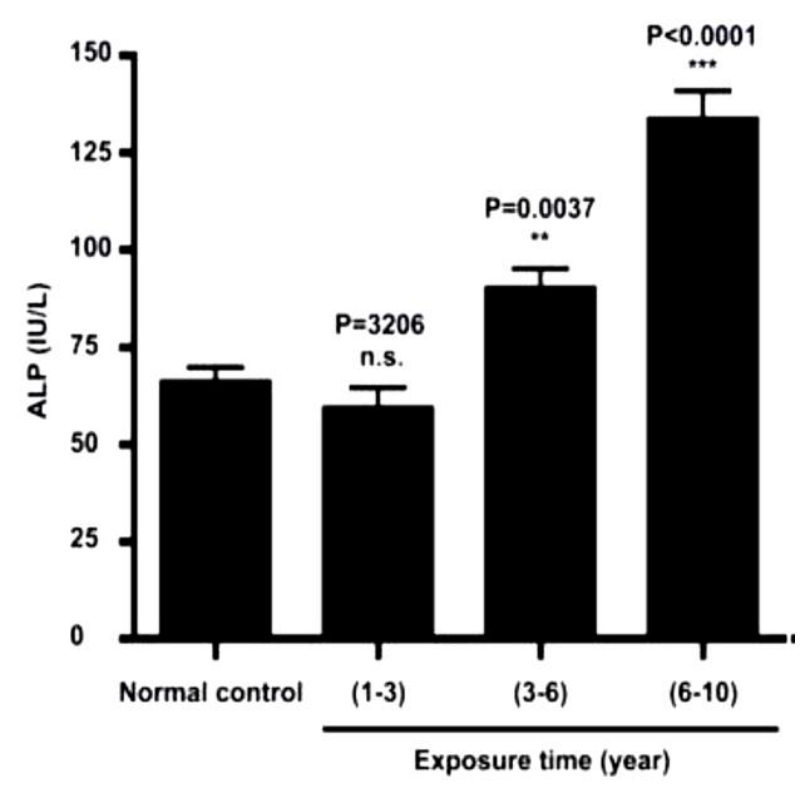

Fig.(3): ALP level in petrol station workers compared with non-exposed subjects. Asterisks indicate statistically different. Columns are mean of six determinations. 


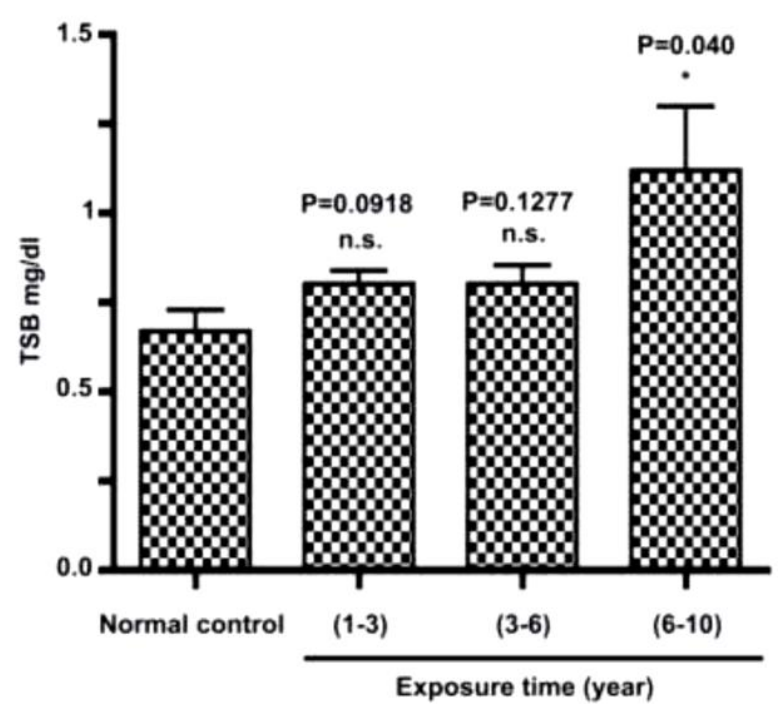

Fig.(4): TSB level in petrol station workers compared with non-exposed subjects. Asterisks indicate statistically different. Columns are mean of six determinations.

The healthy problems due to exposure to petroleum derivatives depending on the many factors such as chemical substance concentration, and time of exposure. Contact with petroleum vapors may be responsible for many diseases such as such as headache, nausea, and respiratory tract allergy [10], [11].

During oxidation and metabolism process the petroleum and other related chemical materials may be converted to free radicals especially in the mammalian liver and kidney cells. These activated free radicals bind with some of cellular components such as enzymes and cause reduce their biological activity [12].

In this study the effect of time exposure to petroleum products and their derivatives that are inhaled by the Iraqi workers was assessed on liver function. In-Vivo experimental models with animals lab. Such as rats refer to that exposure by inhalation to the petroleum product was hepatotoxic and nephrotoxic [13], this effect is not demonstrated in mammalians such as human [14]. Previous reporters on human and animals demonstrated that many chemicals can affect the kidney and liver function $[15,16]$.

\section{Conclusions}

In conclusion, our results showed that long time exposure to petrol fumes could have adverse effects on the liver function. The levels of liver enzymes were significantly elevated in workers; when compared with control group. Previous reports have demonstrated exposure to petroleum have some effects on liver functions. Therefore, We have to advice of petrol station attendants to safe their life and health and this can be achieved by advise them to use nose and mouth masks, although this can't perfect way to stop the exposure to the petrol fumes but it can be reduce it to some certain level.

\section{References}

[1] Micyus N., McCurry J., Seeley J. "Analysis of aromatic compounds in gasoline with flow-switching comprehensive two-dimensional gas chromatography"; J. Chromatogr, 1086, 115-121, 2005.

[2] Chilcoot R.P. "Petrol toxilocal overview"; Toxological overview, 2, 1-16.2007.

[3] Ikeda M., Kumai M., Aksoy M. "n-Hexan and benzene content in gasoline for industrial purposes"; Ind Health., 24, 63-66, 2014.

[4] Lewne M., Nise G., Lind M. "Gustavsson P. Exposure to particles and nitrogen dioxide among taxi, bus lorry drivers". Int. Arch. Occup. Environ. Health., 79, 220226, 2006.

[5] Masoud N., Kiamars H., Jafer A. "Early liver and kidney dysfunction associated with occupational exposure to subthreshold limit value levels of Benzene, Toluene, and Xylene in unleaded petrol"; Saf. And Hea.at Work, 6, 312-316, 2015.

[6] Gali R., Daja A., Mamza Y., Ani G. "Liver enzymes and protein among petrol hawkers and petrol-pump attendants in a Nigerian population"; Adv. Lab. Med. Internat., 2, 123-129, 2012.

[7] Periago J., Prado C. "Evolution of occupational exposure to environmental levels of aromatic hydrocarbons in service stations"; Ann. Occup. Hyg., 49,233-240, 2005.

[8] Gupta S., Dogra T. "Air pollution and human health hazards"; Ind. J. Occup. Environ. Med., 6, 89-93, 2002.

[9]Akiubue P. "Poisons in our Environment and Drugoverdose: A Guide for Health Professionals and thelay public"; Snaps Press LTD, 35. 1997. 
[10] Parasuraman T. "Evaluation of subchronic toxic effects of petroleum ether, a laboratory solvent in Sprague-Dawley rats"; 5, 89-97, 2014.

[11] Nwanjo H., and Ojiako O. "Ivestigation of the health hazards of petrol station attendants in Owerri Nigeria"; JASEM, 11,197-200, 2007.

[12] Stadtman E. "Metal ion-catalyzed oxidation of protein: biochemical mechanism and biochemical consequences"; Free. rad. bio. and. med, 15, 315-325, 1990.

[13] Ogunneye A., Omoboyowa A., Sanibare J., Faniran T. "Hepatotoxic and nephrotoxic effect of petroleum fumes on petrol attendants in Ibadan, Nigeria"; NJBAS, 22, 57-61, 2014.

[14] Melnick R. "An alternative hypothesis on the role of chemically inducedprotein droplet (alpha-2-gamma-globulin) nephropathy in renal carcinogenesis"; Regul. Toxicol. Pharmacol., 16, 111-1251, 1992.

[15] Pfaller W. and Gstraunthaler G. "Nephrotoxicity testing in vitro: what we know and what we need to know"; Environ. Health Perspect, 106, 559-569. 1998.

[16] Revilla A. S., Pestana C.R., Parda G. L., Santos A. C., Gonzalis M. E. "Potential toxicity of toluene and xylene evoked by mitochondrial uncopling"; Toxicol. In Vitro.21, 782-788, 2009.

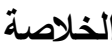

اشتارت العديد من الدراسات السابقة التي اجريت على

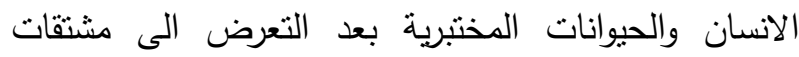

البترول الى التاثيرات المحتملة على وضائف الكبد. الدراسة

الحالية شملت (18) شخص من العاملين في محطات

البترول في محافظة البصرة وشملت ايضا (18) شخص سليم

غير معرض لنلك المشتقات النفطية. في الدراسة الحالية تم

دراسة تاثير استتشاق مشتقات البترول على وضائف الكبد.

أظهرت نتائج الدراسة وجود ارتفاع معنوب ملحوظ في تركيز

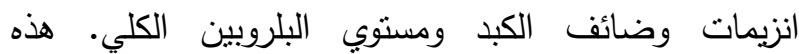

التغيرات في مستوى انزيمات الكبد وكذلك مستوى البلروبين

الكلي قد نرتبط ارتباط مباشر بالفترة الزمنية لتعرض العاملين

في محطات تعبئة الوقود للمشتقات النفطية خاصة بعد فترة
3-6 سنوات و 6-10 سنوات حيث اظهرت فروق معنوية

كبيرة لقيمة الاحتمالية p p $\leq 0.01$, p

اظهرت نتائج الدراسة ان المستوى الكلي للبروتين يتاثز بعد التهد

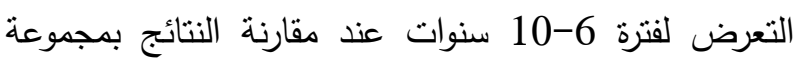

السيطرة. نتائج الدراسة تقترح ان التغيير في وضائف الكبد

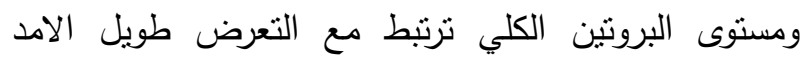
لاستشاق مشتقات البترول. 